\title{
Primary ovarian leiomyoma: a diagnostic dilemma
}

\section{Shradha Prajapati*, Meerabai V., Jayalakshmi M.}

Department of Obstetrics and Gynecology, Karpagam faculty of Medical Science and Research, Othkalmandapam, Coimbtore, Tamil Nadu, India

Received: 15 January 2018

Accepted: 10 February 2018

\section{*Correspondence:}

Dr. Shradha Prajapati,

E-mail: drshradhakanoriya@gmail.com

Copyright: (C) the author(s), publisher and licensee Medip Academy. This is an open-access article distributed under the terms of the Creative Commons Attribution Non-Commercial License, which permits unrestricted non-commercial use, distribution, and reproduction in any medium, provided the original work is properly cited.

\begin{abstract}
Among all benign primary ovarian smooth muscle tumors, ovarian leiomyoma is uncommon accounting for $.5-1 \%$ of all tumors. most of these are unilateral small in size and generally occur in premenopausal women. this paper presents a case report of primary ovarian leiomyoma i.e. 29 years old women with complaints of abdominal pain. the right ovarian mass was histologically diagnosed as ovarian leiomyoma. unlike other smooth muscle tumors of uterine origin, there are no definite histological criteria to categorize smooth muscle tumor of ovary.
\end{abstract}

Keywords: Leiomyoma, Magnetic resonance imaging, Ovarian tumor

\section{INTRODUCTION}

Primary ovarian leiomyoma is a rare benign tumor of ovary seen in women between $20-65$ years. It accounts for $0.5-1 \%$ of all benign ovarian tumor. ${ }^{1}$

Ovarian leiomyoma is particularly unilateral and small but they may reach big size upto $11 \mathrm{~kg}$. It usually occurs in premenopausal women most of these tumors are discovered incidently. ${ }^{2}$

Patients are usually asymptomatic, and the tumor is most commonly diagnosed unintentionally by histopathological examination of ovarian tissue after an ovariectomy for solid ovarian mass.

Ovarian leiomyoma probably arises from smooth muscle cell in the ovarian hilar blood vessels, but other possible origin are cells in ovarian ligaments, smooth muscle cells or multipotential cells in the ovarian stroma, undifferentiated germ cells and cortical smooth muscle metaplasia. ${ }^{3}$ Ovarian leiomyoma concomitantly seen with uterine leiomyoma $(78 \%)$, that suggest an identical hormonal stimulation. ${ }^{4}$
In some instance, MRI can help to determine the preoperative diagnosis, but it may be impossible to delamitate the precise origin of large tumor (uterus subserous versus ovary) on MRI. The tumor appeared as well circumscribed low signal intensity mass on T1 weighted imaging, with mixed signal intensity on $\mathrm{T} 2$ weighted imaging. Areas of high intensity signal on T2 weighted images corresponded to degeneration $f$ leiomyoma. ${ }^{5}$

\section{CASE REPOR'T}

A 29 year old p1L1 women was referred to our hospital for lower abdominal pain and palpable mass at lower abdominal region for 6 months. On examination she was anemic, abdomen shows mass with smooth margin and surface, firm consistency of size $5 * 5 \mathrm{~cm}$ in left iliac fossa. On vaginal examination uterus was normal size and anteverted, left forniceal mass firm to hard consistency of $7 * 6 \mathrm{~cm}$ size freely mobile with minimal tenderness on bimanual examination. a groove felt between mass and uterus. On CT SCAN a well-defined heterogeneously enhancing mass arising from left anterior wall of uterus, left ovary could not separately 
visualized concluding possibility of pedunculated myoma uterus or solid left ovarian mass; she undergone laprotomy.

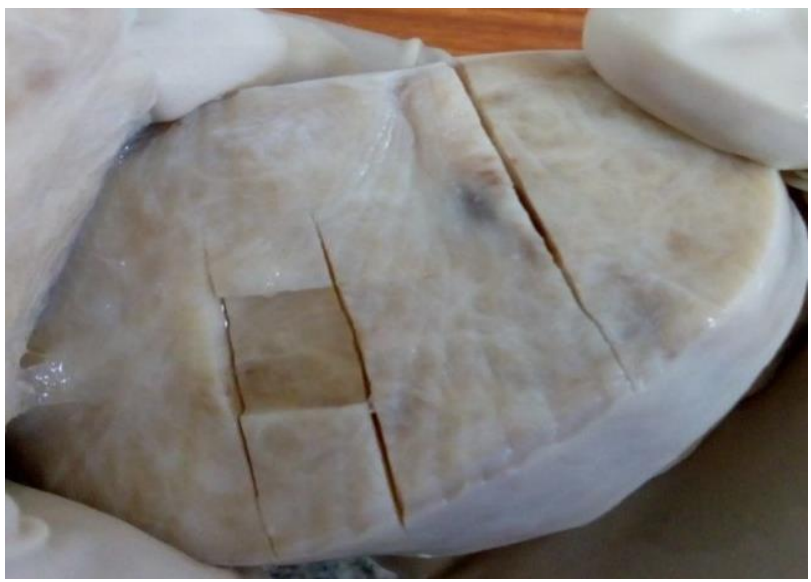

Figure 1: Cut section of ovarian fibroid showing greyish white whorled areas.

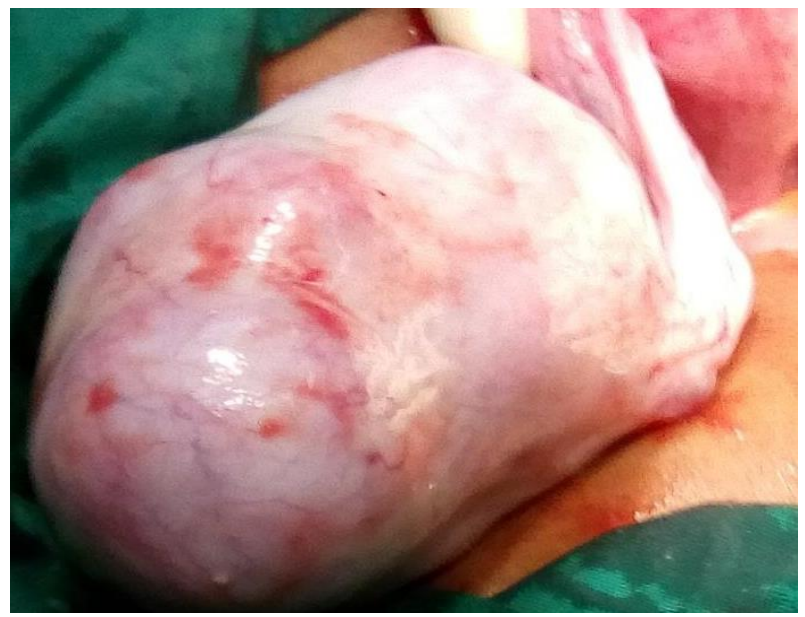

Figure 2: Intra-operative picture of ovarian mass.

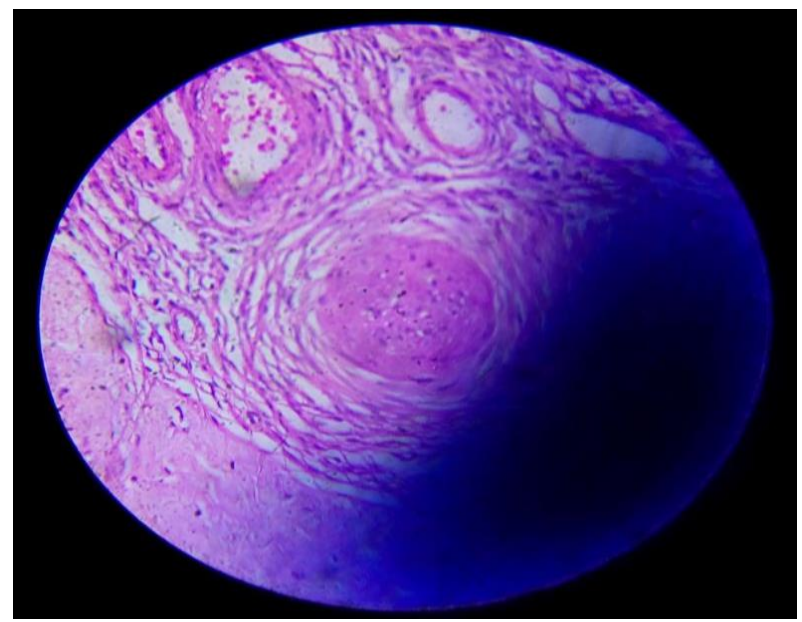

Figure 3: Magnified microscopic view of ovarian fibroid showing smooth muscle separated by connective tissue.

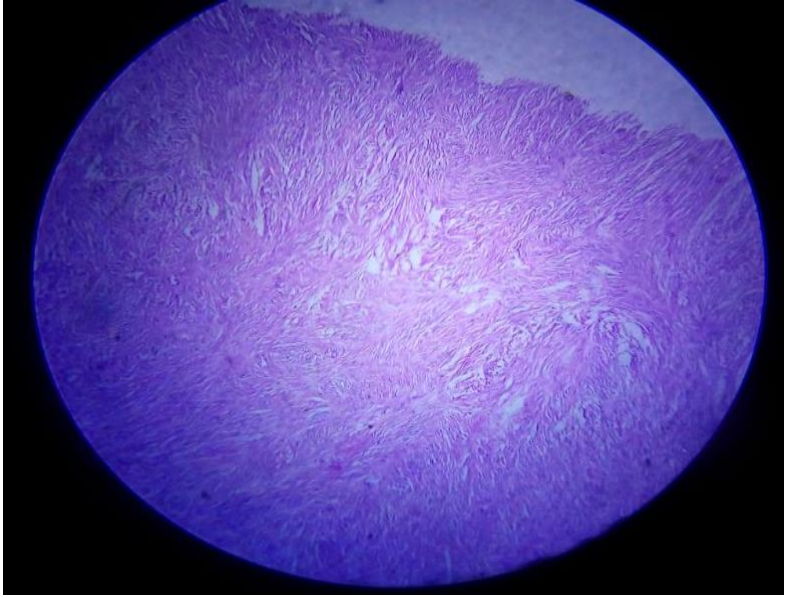

Figure 4: Microscopic view of ovarian fibroid.

During laprotomy on inspection of uterus and adnexes revealed a solid, firm, oval, left sided ovarian tumor with smooth surface approximately $5 * 5 \mathrm{~cm}$. The tumor was distinctly separated from uterus and exhibited no adhesion to or infilteration of surrounding structures. There was no accompanying uterine mass. The right salpinx, ovary was normal on inspection and were left intact (left salpingo-oophrectomy). After surgery histological examination resulted in a diagnosis of ovarian leiomyoma.

\section{DISCUSSION}

Most ovarian leiomyoma have no symptoms and discover either during routine physical examination, incidently at surgery, or at autopsy. In symptomatic cases that often present in large one, clinical manifestation is abdominal pain, palpable mass, hydronephrosis, elevated CA -125 , Meig's syndrome and polumyosistis. ${ }^{6,7}$

Ovarian leiomyoma often misdiagnoses preoperatively as pedunculated uterine myoma, ovarian fibroma or even ovarian endometrioma. ${ }^{8}$

Macroscopic and microscopic manifestations of ovarian leiomyoma are very caharacteristics, but because of its rarity, several other tumors should include in the differential diagnosis. The major differential diagnostic considerations for ovarian leiomyoma is leiomyosarcoma and sex cord stromal tumors, such as fibroma, thecoma, sclerosing stromal tumor. ${ }^{9}$

Ovarian leiomyomas must be also differentiated from leiomyosarcoma but due to rarity of these tumors histologic features of malignancy have not been well defined. Pathologists have traditionally used criteria that stress the mitotic count, but it is evident that some other criteria, such as cytological atypia and tumor necrosis must be used when considering the possibility of malignancy in smooth muscle uterine tumor. ${ }^{3}$ Most of the patients undergone a salpingo-oophrectomy or an oophorectomy with or without hysterectomy despite the 
young age of affliction, and only minor of patients are submitted to ovarian preserving surgery. ${ }^{10-12}$

\section{CONCLUSION}

Ovarian leiomyoma is a very rare tumor of unresolved origin. Despite its rarity ovarian leiomyoma should considered in the differential diagnosis of ovarian spindle cell tumors. Appropriate diagnosis in some cases requires additional immunohistochemical analysis for actin and desmin.

Funding: No funding sources

Conflict of interest: None declared

Ethical approval: Not required

\section{REFERENCES}

1. Agrawal R, Kumar M, Agrawal L, Agrawal KK. A huge primary ovarian leiomyoma with degenerative changes: an unusual. J Clin Diagn Res. 2013;7(6):1152-4.

2. Blue NR, Felix JC, Jaque J. Primary ovarian leiomyoma in a premenarchal adolescent: first reported case. J Pediatr Adolesc Gynecol. 2014 Aug 1;27(4): e87-8

3. Tomas D, Lenicek T, Tuckar N, Puljiz Z, Ledinsky M, Kruslin B. Primary ovarian leiomyoma associated with endometriotic cyst presenting with symptoms of acute appendicitis: a case report. Diagn Pathol. 2009;4:25.

4. Khaffaf N, Khaffaf H, Wuketich S. Giant ovarian leiomyoma as a rare cause of acute abdomen and hydronephrosis. J Obstet Gynecol. 1996;87:872-3.

5. Takeuchi S. A case report of laparoscopic resection of a large leiomyoma of the ovary that required an operation time of seven hours. J Rural Med. 2009;4:35-7.

6. Van Winter JT, Stanhope CR. Giant ovarian leiomyoma associated with ascites and polymyositis. Obstet Gynecol. 1992;80:560-3.

7. Tsalacopoulos G, Tiltman AJ. Leiomyoma of the ovary. A report of 3 cases. S Afr Med J. 1981;59:574-5.

8. Koo YJ, Cho YJ, Kim JY, Lee JE, Kim ML, Kim $\mathrm{JM}$, et al. Ovarian leiomyoma as a potential cause of compromised fertility. Fertil Steril. 2011;95:1120.

9. Usta U, Karadag N, TÜrkmen E, Haltas H. Primary leiomyoma of the ovary. Balkan Med J. 2006;23:3942.

10. Ozcimen EE, Oktem M, Zeyneloglu HB, Ozdemir $\mathrm{BH}$, Kuscu E. Primary leiomyoma of the ovary in a young woman: Literature review and report of a case. Eur J Gynaecol Oncol. 2006;27: 310-2.

11. Yumru AE, Bozkurt M, Ayanoğlu YT, Ayhan I, Inci Coşkun E, Battal Havane S. The relation between the presence of a giant primary ovarian leiomyoma and the occurrence of epilepsy as a paraneoplastic syndrome. Arch Gynecol Obstet. 2010;281:531-4.

12. Güney M, Ozsoy M, Oral B, Mungan T, Kapucuoğlu $\mathrm{N}$. Unilateral primary ovarian leiomyoma in adolescent: a case report. Arch Gynecol Obstet. 2007;275:507-10.

Cite this article as: Prajapati S, Meerabai V, Jayalakshmi M. Primary ovarian leiomyoma: a diagnostic dilemma. Int J Reprod Contracept Obstet Gynecol 2018;7:1645-7. 